\title{
Rural and Urban in Vietnam Economic Structure
}

\author{
Nguyen Hong Nhung ${ }^{1}$, Nguyen Quang Thai ${ }^{2}$, Bui Trinh ${ }^{3}$, Nguyen Viet Phong ${ }^{4}$ \\ ${ }^{1}$ MA Vietnam Development Research Institute, Vietnam \\ ${ }^{2}$ Prof. Dr., Vietnam Development Research Institute, Vietnam \\ ${ }^{3}$ Dr., Vietnam Development Research Institute, Vietnam \\ ${ }^{4}$ MA General statistic Office, Vietnam \\ Correspondence: Bui Trinh, Dr., Vietnam Development Research Institute, Vietnam.
}

Received: January 8, 2019

Accepted: January 23, 2019

Online Published: January 29, 2019

doi:10.5539/ibr.v12n3p31

URL: https://doi.org/10.5539/ibr.v12n3p31

\begin{abstract}
Vietnam is an agricultural country with a "wet rice" culture. In recent decades, in addition to the achievement of relatively high economic growth, the implementation of poverty reduction, there seems to be the trend of simple "industrialization and modernization" almost in all localities of country. Vietnam instead of using forte be cultivated and raised in tropical agriculture into workers and townsman's in an unprepared way. When Vietnamese people's strengths are not used and promoted, they have to try or be forced to use their weakness. So, the failure is almost inevitable.

This study aims to examine the change in the level of interactions between the agriculture, forestry, fisheries and rural sectors with other sectors in the economy and urban areas based on structure of the input - output table has been updated for Vietnam in 2016 by Vietnam Institute of Development Research (implemented 2018 under a Project of Vietnam Union of Science and Technique Associations VUSTA).
\end{abstract}

Keywords: urban, rural, income, consumption, induced impact

\section{Introduction}

When it comes to Vietnamese culture, it refers to the culture of agriculture. Every country has agriculture, but the culture of agriculture is only in some Asian countries, including Vietnam. In the soul of the Vietnamese is always a pure soul and pure. In recent decades it seems that people are trying to change this with the "industrialization and modernization" movement, trying to force the Vietnamese people instead of using the advantages of cultivation, breeding ... become workers. When Vietnamese people's strengths are not used and promoted, they have to try or be forced to use their weakness. So, the failure is almost inevitable. This study examines the change in the interactions between agriculture, forestry and fisheries with other sectors of the economy based on the structure of the 2012 and 2016 input - output tables of Vietnam

Data of the Vietnam general statistics office show that urban population growth rate has increased continuously in the period of 2010 - 2017, the population growth rate of rural areas has been negative or increase negligible in many years. The population structure of the urban area increased from 31.6\% in 2010 to 35\% in 2017. The speed and structure of urban and rural population structure changes relatively quickly basically due to the construction process and urbanization (urban birth rate is not as high as in rural areas), people in rural areas are became into urban people even though thinking and heart are still only agricultural people. When they become something that actually doesn't belong to them can lead to more difficulties in life, or they become "aggressive" and only a few people adapt to the "urban" life. Is this one of the causes in the suburban and new regions that have transformed from rural to urban areas with many social evils? 
Table 1. Urban and rural population growth rates

Unit: \%

\begin{tabular}{lcc}
\hline & Urban & Rural \\
\hline 2010 & 3.64 & -0.01 \\
2011 & 4.54 & -0.48 \\
2012 & 1.98 & 0.66 \\
2013 & 2.14 & 0.57 \\
2014 & 4.02 & -0.31 \\
2015 & 3.44 & -0.08 \\
2016 & 2.76 & 0.20 \\
2017 est. & 2.78 & 0.15 \\
\hline
\end{tabular}

Source: Vietnam general statistics office

Table 2. Urban-rural population structure

Unit: \%

\begin{tabular}{lll}
\hline & Urban & Rural \\
\hline 2010 & 30.50 & 69.50 \\
2011 & 31.55 & 68.45 \\
2012 & 31.83 & 68.17 \\
2013 & 32.17 & 67.83 \\
2014 & 33.10 & 66.90 \\
2015 & 33.88 & 66.12 \\
2016 & 34.44 & 65.56 \\
2017 est. & 35.03 & 64.97 \\
\hline
\end{tabular}

\section{Source: Vietnam general statistics office}

This research used the 2016 Vietnam input - output table. This table updated from 2012 Vietnam national input output table and the enterprise's survey and data of Household Living Standard Survey of Vietnam General Statistics Office 2012-2016. After that, the ras method and ras method with random fixed points for balancing the gross input and gross output of the input - output table.

\section{Literature Reviews}

This research uses input - output analysis in Leontief system (type I) and demographic - economic modeling (type II). Since Leontief's Input-Output System (IOS) came out into $(1936,1941)$, it has been further developed and expanded in many ways by various researchers. Moreover, including originally inter-regional input-output table by as Isard (1951), multi-regional input-output model (MRIO) by Chenery and Moses (1954, 1955), Miller (1957) and Hirsch (1959); Social accounting system by Stone (1961),Pyatt and Rose (1977), demographic economic model was parallel developed with social accounting matrix by Miyazawa (1976) and Madden and Batey (1983). Demographic - Economic model was been developed by Miyazawa for analyzing the structure of income distribution by endogenous consumption expenditures in the standard of Leontief system. It means the Leontief system was extended by a group of consumption expenditures in column and corresponding group of row income. HUSSAIN ALI BEKHET $(2009,2011)$ also used input - output approach in order to decompose of Malaysian production structure and calculating output, income, employment multipliers in Malaysian Economy, this author also used input - output system for Ranking Sectors Changes of the Malaysian economy (2010)

There are some researches on urban and rural relationship such as the research on inequality in the living standards between urban and rural sectors (Mundle, Van Akadie, 1997); Inequality in job search is also shown in the study of Phan and Coxhead (2010).. Thu Le and Booth (2014) also found that, the remittances are the most important in explaining the urban - rural expenditure gap. But this study has no clear evidence of how and why the gap between urban and rural areas increases rapidly

\section{Methodology}

Type I of input-output analysis is based on standard equation of Leontief system:

$$
X=\left(I-A^{d}\right)^{-1} \cdot Y^{d}
$$

In this type, we get power of dispersion and sensitivity of dispersion for output and income from production that is induced by final demand, In this case, $\mathrm{X}$ is matrix of output that induced by factors of final demand, I is unit matrix, $\mathrm{A}^{\mathrm{d}}$ is domestic direct input coefficient, $\mathrm{Y}^{\mathrm{d}}$ is matrix of domestic final demand (these includes urban 
consumption, rural consumption, Government consumption, gross capital formation and export; $\left(\mathrm{I}-\mathrm{A}^{\mathrm{d}}\right)^{-1}$ is a Leontief inverse matrix.

In order to estimate value added induced by a unit of final demand the equation (1) can rewritten as below:

$$
V=v \cdot X=v \cdot\left(I-A^{d}\right)^{-1} \cdot Y^{d}
$$

Where: $\mathrm{V}$ is matrix of value added with rows presents type of income and columns are number of sectors; $\mathrm{v}$ is matrix value added coefficient, with: $\mathrm{v}_{\mathrm{ij}}=\mathrm{V}_{\mathrm{ij}} / \mathrm{X}_{\mathrm{j}}$

And:

$\mathrm{X} \div$ Ydpresent impacts of factors of final demand to output

$\mathrm{V} \div$ Yd presents impacts of factors of final demand to value added

Here: $\div$ shows scalar division

Type II is an expansion Leontief system and Miyazawa model. The study considers the following systems:

$$
\begin{array}{cl}
\mathrm{A} \cdot \mathrm{X}+\mathrm{c}_{1} \cdot \mathrm{T}_{1}+\mathrm{c}_{2} \cdot \mathrm{T}_{2}+\mathrm{F} & =\mathrm{X} \\
\mathrm{V}_{1} \cdot \mathrm{X}+\mathrm{V}^{\prime}{ }_{1} & =\mathrm{T}_{1} \\
\mathrm{~V}_{2} \cdot \mathrm{X}+\mathrm{V}^{\prime}{ }_{2} & =\mathrm{T}_{2}
\end{array}
$$

Where:

A is matrix of input coefficient;

$\mathrm{X}$ is a vector of output;

$\mathrm{V}_{1}$ is a vector coefficient of urban endogenous income

$\mathrm{V}_{2}$ is a vector coefficient of rural endogenous income

$\mathrm{V}^{\prime}{ }_{1}$ is a vector of exogenous income of urban areas

$\mathrm{V}^{\prime}{ }_{1}$ is a vector of exogenous income of rural areas

$\mathrm{T} 1$ and $\mathrm{T} 2$ are total income of urban areas and rural areas corresponding

$\mathrm{C}_{1}$ is a vector coefficient of household consumption of urban area,

$\mathrm{C}_{1}$ is a vector coefficient of household consumption of rural area,

$F$ is rest of domestic final demand

The equation system (2), (3) and (4) can be rewritten in a matrix form as below:

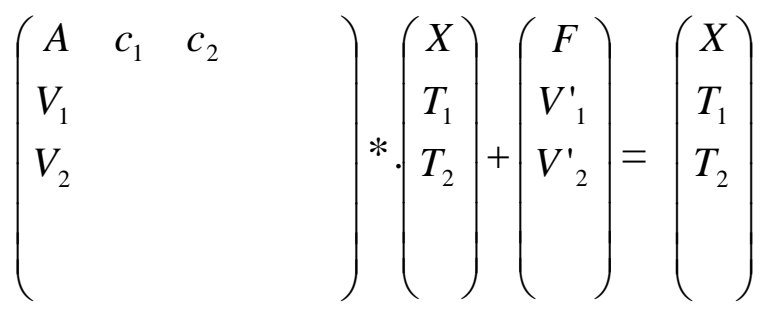

The equation (5) goes back Standard Leontief equation with endogenous and exogenous variables of incomes and expenditures

Put: 


$$
\mathrm{B}=\left(\begin{array}{lll}
A & c_{1} & c_{2} \\
V_{1} & & \\
V_{2} & & \\
& &
\end{array}\right)
$$

From (6), we have:

$$
\left(\begin{array}{c}
X \\
T_{1} \\
T_{2}
\end{array}\right)=(\mathrm{I}-\mathrm{B})^{-1} \cdot\left(\begin{array}{c}
F \\
V_{1}^{\prime} \\
V_{2}^{\prime}
\end{array}\right)
$$

Where $\mathrm{I}$ is a unit matrix and Put: $\mathrm{L}=(\mathrm{I}-\mathrm{B})^{-1}$

$$
\mathrm{L}=(\mathrm{I}-\mathrm{B})^{-1}=\left(\begin{array}{ccc}
L^{A} & L^{C_{1}} & L^{c_{2}} \\
L^{V_{1}} & & \\
L^{V_{2}} & & K \\
& &
\end{array}\right)
$$

L is computed based on Sonis and Hewings work (1993) where:

$\mathrm{L}^{\mathrm{A}}$ is called enlarged Leontief inverse matrix. It includes multiplier effects $(\mathrm{I}-\mathrm{A})^{-1}$ and induced feedback effects by $L^{\mathrm{c} 1}, L^{\mathrm{c} 2}$. Based on Sonis and Hewings (1993) we have:

$$
\mathrm{L}^{\mathrm{A}}=\left(\mathrm{I}-\mathrm{A}-\mathrm{c}_{1} \mathrm{~V}_{1}-\mathrm{c}_{2} \mathrm{~V}_{2}\right)
$$

$\mathrm{L}^{\mathrm{V} 1}, \mathrm{~L}^{\mathrm{V} 2}$ are spillover effects caused byconsumption.

$\mathrm{K}$ is an enlarged matrix of Miyazawa interrelation income multipliers. This means exogenous. Since we have:

$$
\mathrm{K}=\mathrm{I}+\mathrm{M}\left(\mathrm{V}_{1}, \mathrm{~V}_{2}\right) \cdot \mathrm{L}^{\mathrm{A}} \cdot \mathrm{M}\left(\mathrm{c}_{1}, \mathrm{c}_{2}\right) \text {. }
$$

It implies that final expenditure stimulates income outside of production

So, Formula (7) can be rewritten:

$$
\mathrm{L}=\left[\begin{array}{cc}
L^{A} & L^{A} \cdot M(c, g, k) \\
M\left(V_{1}, V_{2}, V_{3}\right) \cdot L^{A} & I+M\left(V_{1}, V_{2}, V_{3}\right) \cdot L^{A} \cdot M(c, g, k)
\end{array}\right]
$$

\section{Some Findings}

After balancing the input - output table, results show that gross value added balanced from the input - output table and gross value added published before has gap 1,7\%. The comparing on income structure from input output table in 2012 and 2016 shows that the income structure of urban areas in 2016 is higher than 2012 by 0.9 and income structure of rural areas in Total value added also increased.So, income from capital decreased by $1.7 \%$. This shows that the economy needs more capital to create a value-added unit? If this happens in a good way, the productivity will increase and the employee will be paid more. 
Table 3. Share of labor and share of capital

\begin{tabular}{ccc}
\hline & \% contribute & \% contribute \\
\hline Gross value added at basic price & 100 & 100 \\
Share of Urban income & 31.9 & 31 \\
Share of Rural income & 33.8 & 33 \\
Share of capital & 34.3 & 36 \\
\hline
\end{tabular}

Source: Vietnam input - output tables, 2012, 2016

A closer look at the structure of income from production and final consumption of the economy of rural and urban areas shows that if the period 2010-2014 (2012 input - output table represents) the proportion of income from production only 94\% compared to final consumption, in the period of 2014 - 2018 (the 2016 input - output table represents) this rate dropped to $92 \%$. Note that according to the calculation of the National account in income from production, including social insurance and union funds. This suggests that income from both urban and rural production is not enough for the final consumption of households. These ratios tend to decrease, even though GDP continues to increase (GDP growth average in period of $2010-2017$ is about 6.2\%)

Table 4. Ratios between income from production and household consumption

By urban and rural areas

Unit: \%

\begin{tabular}{ccc}
\hline & 2016 & 2012 \\
\hline Urban & $93.7 \%$ & $95.7 \%$ \\
Rural & $90.5 \%$ & $92.2 \%$ \\
Total & $92.0 \%$ & $94 \%$ \\
\hline
\end{tabular}

Table 6 shows some remarkable points:

+ The final consumption of rural areas induces to the income of urban areas more than the final consumption of urban areas induced to rural incomes (0.093 compared to 0.079).

+ It is noteworthy that government expenditure (recurrent expenditure) basically spread to the income of the urban area, this factor spread to urban income 3.09 times higher than radiating to rural income

+ Export of goods almost spread to very little income, both for urban and rural areas

+ Basic service exports spread to the income of urban areas

+ A unit of export of goods induced impacts poorly to urban areas, because agro-forestry and fishery products have not been fully outsourcing processed as products of processing industry.

Table 5. Induced impacts the factors of final demand to income of urban and rural areas

Unit: \%

\begin{tabular}{lccccccc}
\hline & $\begin{array}{c}\text { Urban final } \\
\text { consumption }\end{array}$ & $\begin{array}{c}\text { Rural final } \\
\text { consumption }\end{array}$ & $\begin{array}{c}\text { Government } \\
\text { consumption }\end{array}$ & $\begin{array}{c}\text { Gross capital } \\
\text { formation }\end{array}$ & $\begin{array}{c}\text { Export of } \\
\text { goods }\end{array}$ & $\begin{array}{c}\text { Export of } \\
\text { services }\end{array}$ & $\begin{array}{c}\text { Total } \\
\text { export }\end{array}$ \\
\hline Urban & 0.110 & 0.093 & 0.282 & 0.084 & 0.059 & 0.149 & 0.066 \\
Rural & 0.079 & 0.101 & 0.091 & 0.083 & 0.069 & 0.071 & 0.069 \\
\hline
\end{tabular}

+ In general, final demand induces impact to rural incomes higher than that of urban areas (0,236 compared to $0,152)$

+ Notably, the final demand on services induce impact strongly to urban areas

+ Most of the final demand of agriculture, fisheries and manufacturing on agricultural products spreading to rural incomes higher than the average level.

Table 6. Income from production induced by a unit rising of the final demand

Unit: Times

\begin{tabular}{lcccc}
\hline Urban & Rural & $\begin{array}{c}\text { Power of dispersion on } \\
\text { income of Urban area }\end{array}$ & $\begin{array}{c}\text { Power of dispersion on } \\
\text { income of rural area }\end{array}$ \\
\hline $\mathbf{1}$ & 0.068 & 0.373 & 0.445 & 2.449 \\
$\mathbf{2}$ & 0.070 & 0.373 & 0.457 & 2.447 \\
$\mathbf{3}$ & 0.086 & 0.256 & 0.565 & 1.680 \\
$\mathbf{4}$ & 0.099 & 0.419 & 0.648 & 2.748 \\
$\mathbf{5}$ & 0.020 & 0.166 & 0.133 & 1.089 \\
$\mathbf{6}$ & 0.035 & 0.693 & 0.231 & 4.552 \\
$\mathbf{7}$ & 0.013 & 0.294 & 0.087 & 1.929 \\
$\mathbf{8}$ & 0.028 & 0.424 & 0.185 & 2.786 \\
\hline
\end{tabular}




\begin{tabular}{|c|c|c|c|c|}
\hline 9 & 0.043 & 0.546 & 0.283 & 3.587 \\
\hline 10 & 0.066 & 0.247 & 0.431 & 1.622 \\
\hline 11 & 0.077 & 0.361 & 0.505 & 2.368 \\
\hline 12 & 0.157 & 0.139 & 1.032 & 0.912 \\
\hline 13 & 0.147 & 0.249 & 0.965 & 1.633 \\
\hline 14 & 0.126 & 0.292 & 0.830 & 1.920 \\
\hline 15 & 0.096 & 0.288 & 0.633 & 1.891 \\
\hline 16 & 0.113 & 0.102 & 0.745 & 0.668 \\
\hline 17 & 0.090 & 0.299 & 0.589 & 1.964 \\
\hline 18 & 0.111 & 0.283 & 0.730 & 1.861 \\
\hline 19 & 0.101 & 0.247 & 0.663 & 1.624 \\
\hline 20 & 0.142 & 0.120 & 0.932 & 0.790 \\
\hline 21 & 0.118 & 0.099 & 0.777 & 0.653 \\
\hline 22 & 0.130 & 0.126 & 0.850 & 0.825 \\
\hline 23 & 0.119 & 0.108 & 0.778 & 0.706 \\
\hline 24 & 0.204 & 0.184 & 1.340 & 1.206 \\
\hline 25 & 0.180 & 0.167 & 1.183 & 1.096 \\
\hline 26 & 0.265 & 0.211 & 1.739 & 1.388 \\
\hline 27 & 0.175 & 0.151 & 1.149 & 0.992 \\
\hline 28 & 0.233 & 0.165 & 1.527 & 1.083 \\
\hline 29 & 0.223 & 0.082 & 1.465 & 0.540 \\
\hline 30 & 0.287 & 0.066 & 1.882 & 0.430 \\
\hline 31 & 0.297 & 0.253 & 1.947 & 1.664 \\
\hline 32 & 0.444 & 0.084 & 2.913 & 0.550 \\
\hline 33 & 0.339 & 0.214 & 2.225 & 1.402 \\
\hline 34 & 0.209 & 0.194 & 1.372 & 1.271 \\
\hline 35 & 0.175 & 0.091 & 1.152 & 0.600 \\
\hline 36 & 0.398 & 0.130 & 2.612 & 0.856 \\
\hline Average & 0.152 & 0.236 & & \\
\hline
\end{tabular}

Table 7 shows final demand of rural area induced impact to income of rural area stronger than final demand of urban area induced impact to income of urban, especial, final demand the products agriculture, forestry and fishery products and manufacturing on agriculture product. Remain manufacturing and services induce impact to income of urban area higher than them of rural area.

Table 7. Income multipliers in Miyazawa model

Unit: Times

\begin{tabular}{|c|c|c|}
\hline Sectors & Urban & Rural \\
\hline 1 & 0.097 & 0.406 \\
\hline 2 & 0.099 & 0.406 \\
\hline 3 & 0.112 & 0.284 \\
\hline 4 & 0.135 & 0.459 \\
\hline 5 & 0.032 & 0.179 \\
\hline 6 & 0.076 & 0.742 \\
\hline 7 & 0.030 & 0.314 \\
\hline 8 & 0.054 & 0.455 \\
\hline 9 & 0.077 & 0.587 \\
\hline 10 & 0.088 & 0.272 \\
\hline 11 & 0.107 & 0.394 \\
\hline 12 & 0.188 & 0.169 \\
\hline 13 & 0.181 & 0.285 \\
\hline 14 & 0.160 & 0.328 \\
\hline 15 & 0.125 & 0.320 \\
\hline 16 & 0.135 & 0.124 \\
\hline 17 & 0.118 & 0.330 \\
\hline 18 & 0.142 & 0.317 \\
\hline 19 & 0.129 & 0.277 \\
\hline 20 & 0.169 & 0.147 \\
\hline 21 & 0.141 & 0.122 \\
\hline 22 & 0.155 & 0.152 \\
\hline 23 & 0.141 & 0.131 \\
\hline 24 & 0.244 & 0.224 \\
\hline 25 & 0.215 & 0.202 \\
\hline 26 & 0.315 & 0.261 \\
\hline 27 & 0.209 & 0.185 \\
\hline 28 & 0.275 & 0.207 \\
\hline 29 & 0.260 & 0.118 \\
\hline
\end{tabular}




\begin{tabular}{ccc}
\hline 30 & 0.332 & 0.109 \\
31 & 0.353 & 0.310 \\
32 & 0.513 & 0.150 \\
33 & 0.400 & 0.274 \\
34 & 0.250 & 0.235 \\
35 & 0.206 & 0.121 \\
36 & 0.463 & 0.193 \\
Average & $\mathbf{0 . 1 9}$ & $\mathbf{0 . 2 7}$ \\
\hline
\end{tabular}

Miyazawa multipliers shows requirement on total income (income from production and income from property and transfer income) for a unit of final consumption, or in other words, a unit of final consumption excite to total income

Table 8 shows the requirement for non - productive income of urban area higher than this requirement of rural area, a unit of final consumption of urban area require 0.15 unit income from non - productive of this area, while a unit final consumption of rural area require 0,05 unit income from non - productive of rural area.

Table 9 also shows final consumption of this area is not only induce impact to income of themselves but also induce impact to income of other area

Table 8. Miyazawa Multiplier

Unit: Times

\begin{tabular}{llcc}
\hline & & & Consumption \\
\cline { 2 - 4 } Income & Urban & Rural \\
& Urban & 1.147 & 0.051 \\
& Rural & 0.138 & 1.063 \\
& Total & 1.285 & 1.115 \\
\hline
\end{tabular}

\section{Conclusions}

The study tries to provide a relationship between economic structure and income and consumption of urban and rural areas. It also shows the relationship between economic sectors and rural and urban sectors and the reciprocal relationship between the final consumption of each area induce impact to income of themself and income of other area. During 2012-2016, urban share of population had increasing, but the gap of income between urban and rural was changed not very large due to efficiency of modernization not very high.

Based on input - output tables type I and II in period 2012-2016, it can show: The final consumption of rural areas induces to the income of urban areas more than the final consumption of urban areas induced to rural incomes. It is noteworthy that government expenditure (recurrent expenditure) basically spread to the income of the urban area, this factor spread to urban income 3.09 times higher than radiating to rural income. A unit of export of goods induced impacts poorly to urban areas, because agro-forestry and fishery products have not been fully outsourcing processed as products of processing industry.Notably, the final demand on services induce impact strongly to urban areas. Most of the final demand of agriculture, fisheries and manufacturing on agricultural products spreading to rural incomes higher than the average level.In general, final demand induces impact to rural incomes higher than that of urban areas. Most of the final demand of agriculture, fisheries and manufacturing on agricultural products spreading to rural incomes higher than the average level.Final demand of rural area induced impact to income of rural area stronger than final demand of urban area induced impact to income of urban, especial, final demand the products agriculture, forestry and fishery products and manufacturing on agriculture products. Remain manufacturing and services induce impact to income of urban area higher than them of rural area.Final consumption of this area is not only induce impact to income of themselves but also induce impact to income of other area, it reflex relationship in economy step by step closing...

I hope that this research can help policy makers consider options when making general policies under modernization in new conditions

\section{References}

Bah, M., Cisse, S., Diyamett, B., Diallo, G., Lerise, F., Okali, D., ... Tacoli, C. (2003). Changing ruralurban linkages in Mali, Nigeria and Tanzania, Environmental and Urbanization, 15(1), April.

Batey, P. W. J., \& Madden, M. (1983). The Modeling of Demographic-economic Change within the Context of Regional Decline: Analytical Procedures and Empirical Results. Socio-Economic Plan, 17(5), 315-328. https://doi.org/10.1016/0038-0121(83)90038-1

Bui, T., Kiyoshi, K., \& Pham, L. H. (2012). The Expansion Input - Output Tables. Global Journal of HUMAN 
SOCIAL SCIENCE Sociology, Economics \& Political Science, 12(14), Version 1.0.

Bui, T., Kiyoshi, K., Pham, L. H., \& Nguyen, V. P. (2012). Vietnamese economic structural change and policy implications". Global Journal of Human-Social Science Research, 12(9c).

Bui, T., Kiyoshi, K., Trung-Dien, V., Pham, L. H., \& Nguyen, V. P. (2012). "New Economic Structure for Vietnam Toward Sustainable Economic Growth in 2020". Global Journal of HUMAN SOCIAL SCIENCE Sociology Economics \& Political Science, 12(10).

Chenery, H. B., \& Watanabe, T. (1958). Internationalcomparisons of the structure of production. Econometricav. 26, 487-521, 958. https://doi.org/10.2307/1907514

Dabson, B., Jensen, J. M., Okagaki, A., Blair, A. P., \& Carrol, M. M. (2012). Case Studies of Wealth Creation and Rural-Urban Connections, MO: Rural Futures Lab, www.ruralfutureslab.org

Diep, P., \& Ian, C. (2010). Inter-provincial migration and inequality during Vietnam's transition. Journal of Development Economics, 91(1), 100-112. https://doi.org/10.1016/j.jdeveco.2009.06.008

Feldman, S. (1999). Rural-Urban Linkages in Asia: Contemporary Themes and Policy Directions, paper prepared for a Workshop on 55 Poverty Reduction and Social Progress: New Trends and Emerging Lessons, A Regional Dialogue and Consultation on WDR2001 for South Asia, Rajendrapur, Bangladesh, 4-6 April.

Geoffrey, J. D. (1999). Hewings, Michael Sonis, Moss Madden and Yoshio Kimura. Introduction Understanding and Interpreting Economic Structure. Springer - Verla, Heidelberg, Germany.

Huong, T. L., \& Alison, L. B. (2014). Inequality in Vietnamese Urban-Rural Living Standards, 1993-2006. Review of Income and Wealth, 60(4), 862-886.

Hussain, A. B. (2009) Decomposition of Malaysian Production Structure Input-Output Approach. International Business Research, 2(4).

Hussain, A. B. (2010). Ranking Sectors Changes of the Malaysian Economy: Input-Output Approach. International Business Research, 3(1).

Hussain, A. B. (2011). Output, Income and Employment Multipliers in Malaysian Economy: Input-Output Approach. International Business Research, 4(1).

Leontief, W. W. (1936). "Quantitative Input and Output Relations in the Economic Systems of the United States". The Review of Economics and Statistics, 18, 105-125. https://doi.org/10.2307/1927837

Miller, R., \& P. Blair. (1985). Input-Output Analysis: Foundations and Extensions, Chapter 7 (pp. 236-260), Environmental Input-Output Analysis, Prentice-Hall.

Miyazawa, K. (1976). Input-Output Analysis and the Structure of Income Distribution. Lecture Notes in Economics and Mathematical Systems, Berlin: Spinger-Verlag. https://doi.org/10.1007/978-3-642-48146-8

Pyatt, G., \& J. I. Round (eds). (1985). SAMs: A Basis for Planning. World Bank, Washington, D.C.

Pyatt, G., \& Roe, A. N. (1977). Social Accounting for Development Planning with Special Reference to Sri-Lanka, Cambridge: Cambridge University Press.

Sonis M., \& Hewings, G. J. D. (1999). Miyazawa's contributions to understanding economic structure: interpretation, evaluation and extensions, Understanding and interpreting economic structure. Springer, ISBN 3540660453. 1999, 13-51.

Sudipto, M., \& Van, A. (1997). The rural - urban transition in Vietnam, report of ADB.

Trinh, B., \& Phong, N. V. (2013). "A Short Note on RAS Method,". Advances in Manage report of ment and Applied Economics, 3(4), 133-137.

Trinh, B., Phong, N.V., \& Quoc, B. (2018). "The RAS Method with Random Fixed Points" The Asian Institute of Research. Journal of Economics and Business, 1(4), 640-646. https://doi.org/10.31014/aior.1992.01.04.57

Vietnam, GSO (2014). "Vietnam input - output table, 2012" Statistics Publisher.

Wassily, L. (1941). Structure of the American economy, 1919-1929.Harverd University Press: Cambridge Mass. 


\section{Appendix: Sectors}

\begin{tabular}{|c|c|}
\hline Annual tree products & 1 \\
\hline Perennial tree products & 2 \\
\hline Livestock products & 3 \\
\hline Agricultural services & 4 \\
\hline Other agricultural products have not been classified yet & 5 \\
\hline Forest planting and tending products & 6 \\
\hline Timber extraction & 7 \\
\hline Other exploited forest products; products collected from the forest & 8 \\
\hline Forestry service & 9 \\
\hline Aquatic products exploited & 10 \\
\hline Aquaculture products & 11 \\
\hline Mining products & 12 \\
\hline Processed products preserve meat and meat products & 13 \\
\hline Fishery and aquatic products processed and preserved & 14 \\
\hline Processed vegetables & 15 \\
\hline Milk and dairy products & 16 \\
\hline Milling products and powder production & 17 \\
\hline Feed for cattle, poultry and aquatic products & 18 \\
\hline $\begin{array}{l}\text { Products processed from wood, bamboo (including beds, cabinets, tables, chairs); from straw, plaited } \\
\text { plaited materials }\end{array}$ & 19 \\
\hline Fertilizers and nitrogen compounds & 20 \\
\hline Pesticides and other chemical products used in agriculture & 21 \\
\hline The remaining processing and manufacturing products & 22 \\
\hline Electricity, gas, hot water, steam and air conditioning & 23 \\
\hline Natural water extraction & 24 \\
\hline Construction products & 25 \\
\hline Wholesale and retail services; repair services for cars, motorcycles, motorbikes and other motor vehicles & 26 \\
\hline Warehouse transport services & 27 \\
\hline Accommodation and catering services & 28 \\
\hline Information and communication services & 29 \\
\hline Banking and insurance financial services & 30 \\
\hline Real estate business services & 31 \\
\hline Other professional, scientific and technological services & 32 \\
\hline Education and training services & 33 \\
\hline Health services and social assistance & 34 \\
\hline Art, entertainment and entertainment services & 35 \\
\hline Other services & 36 \\
\hline
\end{tabular}

\section{Copyrights}

Copyright for this article is retained by the author(s), with first publication rights granted to the journal.

This is an open-access article distributed under the terms and conditions of the Creative Commons Attribution license (http://creativecommons.org/licenses/by/4.0/). 